\title{
Relationship between Socio-Economic Variables and Production and Income in Agriculture - A Multifactor Analysis
}

\author{
J.K. Das ${ }^{1 *}$ and Lawanrisha Lyngdoh ${ }^{2}$ \\ ${ }^{1}$ Department of Agricultural Extension, MS Swaminathan School of Agriculture, Centurion \\ University of Technology and Management, Parlakhemundi, Odisha, India \\ ${ }^{2}$ Department of Agricultural Extension, Punjab Agricultural University, Ludhiana, India \\ *Corresponding author
}

\begin{tabular}{|l|}
\hline Ke y w o r d s \\
$\begin{array}{l}\text { Socio-economic, } \\
\text { Relationship, Yield, } \\
\text { Income }\end{array}$ \\
\hline Article Info \\
\hline $\begin{array}{l}\text { Accepted: } \\
\text { 07 June } 2019 \\
\text { Available Online: } \\
\text { 10 July } 2019\end{array}$ \\
\hline
\end{tabular}

\section{A B S T R A C T}

The state of Meghalaya is blessed with abundant rainfall, fertile soil, diversity in natural resources and having a strong base in traditional knowledge, which have made it favorable for its Agricultural growth but still there is a decline in agricultural output. Land degradation due to loss of fertility and lots of other bio-physical and socio-economic causes paves the way for food insecurity, livelihood and affecting the economy of the state as a whole. The study was carried out in different altitudes of the state to find out the relationship between socio-economic factors with the yield and income of the paddy growing farmers. A multistage purposive and probability proportional to size sampling method was used for drawing a total sample of one hundred twenty from three altitude of the hill. There were twelve independent variables $\left(\mathrm{X}_{1}-\mathrm{X}_{12}\right)$ and two dependent variables (Yield $\mathrm{Y}_{1}$ and Income $\mathrm{Y}_{2}$ ) were selected for the present study. Appropriate statistical tools used in the study for analysis of the data. The analysis of the result shows that family type (' $t$ ' value of $2.990^{* *}$ ) and Mass media (' $t$ ' value $4.280^{* *}$ ) have recorded a significant impact at $\mathrm{p}=0.01$ level of significance on Yield $\left(\mathrm{Y}_{1}\right)$. Education (' $\mathrm{t}$ ' value of $2.991 * *$ ) and land holding (' $\mathrm{t}$ ' value of $2.691 * *$ ) recorded the significant impact at $\mathrm{p}=0.01$ level of significance on Income $\left(\mathrm{Y}_{2}\right)$. All those variables are the keys for the enhancement of the yield $\left(R^{2} 0.497\right)$ and income $\left(R^{2} 0.585\right)$ of the family.

\section{Introduction}

Agriculture is the main occupation of the people of Meghalaya. About $83 \%$ of the total population of state depends on agriculture for their livelihood. However, agricultural land is accounted as only $48 \%$ of the total geographical area of the state. The state offers scope for cultivation of a wide variety of agricultural crops because of highly diversified topography, altitude and climatic conditions. Shifting cultivation or slash and burn agriculture is the most prevalent form of agricultural practice of the ethnic people and is commonly called Jhum or Swidden cultivation, which is one of the most ancient systems of farming believed to have originated in the Neolithic period around 7000 B C (Borthakur, 1982). This system is a primitive cultivation technique and is transition between 
food gathering and hunting to food production. The system of farming is still in vogue in Meghalaya as well as whole northeast Himalayan region (Singh et al., 2000). The ethnic communities of Meghalaya follow two major types of agricultural practices such as shifting cultivation or slash and burn agriculture, and terrace or bun cultivation. Shifting cultivation is practiced in and around forests, and terrace cropping is practiced in valleys and foothills, and inside plantation forests. Even though there are several constraints in hill agriculture, socio economic factors play an important role to harness the production potential of hill agriculture. Therefore, the present study is conducted to find out the relationship between yield, income and socio economic characteristics of the respondents and to show the differences in yield and income in different altitudes. These traditional systems of cultivation practices are well adapted to the environmental conditions and the traditional knowledge of indigenous communities growing cereals and other agricultural crops have enabled them to maintain an ecological balance. Enormous increases in human population have led to massive coverage of land under shifting cultivation. Besides shifting cultivation and bun agriculture, there are some other potential indigenous farming systems in northeast India developed by the tribal farmers using their ingenuity and skill. The agricultural landscape in rural Meghalaya, a hill state in northeastern India, has over large areas changed from shifting cultivation directly to commercial cropping, possibly impacting the local agriculture, food system, and the hill environment, with potential implications for food security as the food habits are closely linked to the agricultural system (Behera et al., 2016).

Elevation plays a large role in the health and growth of plants. Elevation may affect the type and amount of sunlight that plants receive, the amount of water that plants can absorb and the nutrients that are available in the soil. Maibangsa (1998) reported that certain plants grow very well in high elevations, whereas others can only grow in middle or lower elevations.

\section{Study area}

The state of Meghalaya lies between 25.4726.10N latitude and 89.45-92.47 E longitude which offers a spectrum of sylvan surroundings, diverse cultural inheritance and luxurious flora and fauna. Being one of the seven sisters of the North-eastern region, Meghalaya is bounded by Assam on the North and East, and on the west partly by Assam and Bangladesh.

The natural resources degradation, shrinking forest cover and loss of biodiversity are the issues of greatest concern for sustainable development of agriculture in the NorthEastern Hill (NEH) region of India.

The major food crops grown in the state are rice, maize and potato. Besides vegetables all kinds of horticultural crops such as citrus fruits, banana, pineapple, peach, plum, strawberry, etc. are grown in abundance. Among the spice crops - ginger, turmeric, cinnamons are grown commonly in different parts of the state. Jute, mesta and cotton are produced mainly in the Garo hills. In addition, many indigenous crops containing aromatic, medicinal and pesticidal properties are found in the state. It is also noted for the presence of various kinds of orchids. Meghalaya has about 300 of the world's orchid's species growing in its rich, forestland, gardens and nurseries. These rare specimens include the insect eating pitcher plant, Wild Citrus and Pigmy Lily. Since time immemorial, Areca nut has been grown in Meghalaya as an important commercial crop. Also, the broom plant is a major forest-based resource for the farmers 
here and is distributed widely throughout the state of Meghalaya.

\section{Materials and Methods}

The study was conducted in the state of Meghalaya. Multistage purposive sampling technique was used to select the districts, block and villages since they represent the three altitudes of the state i.e. high, mid and low. The hill agriculture divided on the basis of altitude like, high hills1700-1900 m MSL, mid hills 600-900m MSL and low hills up to 300m MSL (Panwar et al., 2010). According to this, two districts, East Khasi Hills and RiBhoi under which three blocks, Mylliem, Pynursla and Umsning of which three villages (Mylliem Mawiong, Lyngkhat and Bhoirymbong) were selected.

As the common crop grown in all the three altitudes (viz. high, medium and low) was recorded as only paddy, a list of farmers cultivating only paddy were taken as respondents for the study. From each village of high and mid altitude 80 (40 farmers each from high and mid altitude) and from low altitude 40 paddy growing respondents (more numbers of farmers practicing farming there as compared to high and mid altitude) were selected by probability proportional to size sampling method without replacement from a list of paddy growing farmers. A total of 120 paddy farmers were selected as respondents to collect data for the present study.

The variables of the study were developed in consultation with the experts. Single, group and participatory methods were employed to collect the data/information from the respondents. Statistical tools namely, mean, median, mode, standard deviation, coefficient of variation, multiple regression and factor analysis have been used for analyzing the data and presented in tabular form for better comprehension.

\section{Results and Discussion}

Table 1 presents the descriptive analysis on the distribution pattern and distribution nature of different independent variables.

The table 1 revealed that the variable "Age" distributed with a mean value of 44 and S.D. of 9.52 . The coefficient of variance was $21.62 \%$ within the range of $29-70$. It is highly consistent in nature.

The table interpreted that the variable "Education" distributed with a mean value of 2.70 and S.D. of 1.36 the coefficient of variance was $50.22 \%$ within the range of 1-6. It is middle consistent in nature. The table revealed that the variable "Material possession" distributed with a mean value of 3.17 and S.D. of 1.66. The coefficient of variance was $52.21 \%$ within the range of 0-6. It is middle consistent in nature.

The table interpreted that the variable "Caste" distributed with a mean value of 2.06 and S.D. of 0.23 the coefficient of variance was $11.28 \%$ within the range of 2-3. It is highly consistent in nature.

The table interpreted that the variable "Family type" distributed with a mean value of 1.41 and S.D. of 0.49 the coefficient of variance was $34.83 \%$ within the range of $1-2$. It is highly consistent in nature.

The table revealed that the variable "Family size" distributed with a mean value of 1.61 and S.D. of 0.49. The coefficient of variance was $30.15 \%$ within the range of $1-2$. It is highly consistent in nature.

The table revealed that the variable "Occupation" distributed with a mean value of 1.19 and S.D. of 0.39 . The coefficient of variance was $32.80 \%$ within the range of 1-2. It is highly consistent in nature. 
Table.1 Distribution of mean median, mode, standard deviation, coefficient of variance

\begin{tabular}{|c|c|c|c|c|c|c|c|}
\hline ITEMS & Mean & Median & Mode & Minimum & Maximum & $\begin{array}{l}\text { Std. } \\
\text { Deviation }\end{array}$ & C.V. \\
\hline Age $\left(X_{1}\right)$ & 44 & 42 & 40 & 29 & 70 & 9.52 & 21.62 \\
\hline Education $\left(\mathbf{X}_{2}\right)$ & 2.70 & 3 & 3 & 1 & 6 & 1.36 & 50.22 \\
\hline $\begin{array}{l}\text { Material } \\
\text { possession }\left(\mathbf{X}_{3}\right)\end{array}$ & 3.17 & 3 & 3 & 0 & 6 & 1.66 & 52.21 \\
\hline Caste $\left(X_{4}\right)$ & 2.06 & 2 & 2 & 2 & 3 & 0.23 & 11.28 \\
\hline Family type $\left(X_{5}\right)$ & 1.41 & 1 & 1 & 1 & 2 & 0.49 & 34.83 \\
\hline Family size $\left(X_{6}\right)$ & 1.61 & 2 & 2 & 1 & 2 & 0.49 & 30.15 \\
\hline Occupation $\left(\mathbf{X}_{7}\right)$ & 1.19 & 1 & 1 & 1 & 2 & 0.39 & 32.80 \\
\hline House type $\left(\mathbf{X}_{8}\right)$ & 2.86 & 3 & 4 & 1 & 4 & 1.02 & 35.64 \\
\hline $\begin{array}{l}\text { Social } \\
\text { participation }\left(\mathbf{X}_{9}\right)\end{array}$ & 1.14 & 1 & 1 & 1 & 5 & 0.54 & 47.43 \\
\hline $\begin{array}{l}\text { Land holding } \\
\left(\mathbf{X}_{10}\right)\end{array}$ & 1.26 & 1.2 & 1 & 0.35 & 2.7 & 0.59 & 46.48 \\
\hline Mass media $\left(\mathbf{X}_{11}\right)$ & 1.58 & 1.58 & 1.42 & 0.96 & 2.08 & 0.24 & 15.12 \\
\hline $\begin{array}{l}\text { Personal } \\
\text { Cosmopolite }\left(X_{12}\right)\end{array}$ & 1.33 & 1.25 & 1.17 & 0.90 & 2.47 & 0.30 & 22.33 \\
\hline
\end{tabular}

Table.2 Multiple regression analysis: yield $\left(\mathrm{Y}_{1}\right)$ vs. 12 independent variables $\left(\mathrm{X}_{1}-\mathrm{X}_{12}\right)$

\begin{tabular}{|c|c|c|c|c|c|}
\hline \multirow[t]{2}{*}{ Variables } & \multicolumn{2}{|c|}{$\begin{array}{l}\text { Unstandardized } \\
\text { Coefficients }\end{array}$} & \multirow{2}{*}{\begin{tabular}{|c|}
$\begin{array}{l}\text { Standardized } \\
\text { Coefficients }\end{array}$ \\
Beta
\end{tabular}} & \multirow[t]{2}{*}{ t-value } & \multirow[t]{2}{*}{ Sig. } \\
\hline & B & Std. Error & & & \\
\hline (Constant) & -5.130 & 3.983 & & -1.288 & .203 \\
\hline Age $\left(X_{1}\right)$ & .160 & .081 & 257 & 1.967 & .054 \\
\hline Education $\left(\mathbf{X}_{2}\right)$ & .438 & 645 & .331 & 622 & .373 \\
\hline $\begin{array}{l}\text { Material possession } \\
\left(\mathbf{X}_{3}\right)\end{array}$ & -.030 & 2.395 & -.002 & -.012 & .990 \\
\hline Caste $\left(\mathrm{X}_{4}\right)$ & -.601 & 2.192 & -.481 & -.274 & .785 \\
\hline Family type $\left(X_{5}\right)$ & 1.186 & .288 & 0.739 & $2.990 * *$ & .150 \\
\hline Family size $\left(\mathbf{X}_{6}\right)$ & 1.171 & 1.271 & .952 & .922 & .360 \\
\hline Occupation $\left(\mathbf{X}_{7}\right)$ & -3.207 & 1.948 & -2.629 & -1.646 & .105 \\
\hline House type $\left(\mathbf{X}_{8}\right)$ & -.538 & .745 & -.431 & -.722 & .473 \\
\hline $\begin{array}{l}\text { Social participation } \\
\left(\mathbf{X}_{9}\right)\end{array}$ & -1.675 & 1.745 & -1.379 & -.960 & .341 \\
\hline Land holding $\left(\mathrm{X}_{10}\right)$ & -.491 & 1.518 & -.401 & -.324 & .747 \\
\hline Mass media $\left(\mathbf{X}_{11}\right)$ & 2.476 & .578 & 2.029 & $4.280 * *$ & .210 \\
\hline $\begin{array}{l}\text { Personal cosmopolite } \\
\left(\mathbf{X}_{12}\right)\end{array}$ & 2.862 & 3.351 & 2.335 & .854 & .396 \\
\hline
\end{tabular}

$\mathrm{r}>2.2664$ significant at $\mathrm{p}=0.01(* *)$

Multiple R sq-0.497 
Table.3 Multiple regression analysis: Income $\left(\mathrm{Y}_{2}\right)$ vs. 12 independent variables $\left(\mathrm{X}_{1}-\mathrm{X}_{12}\right)$

\begin{tabular}{|c|c|c|c|c|c|}
\hline \multirow[t]{2}{*}{ Variables } & \multicolumn{2}{|c|}{$\begin{array}{l}\text { Unstandardized } \\
\text { Coefficients }\end{array}$} & \multirow{2}{*}{$\begin{array}{c}\text { Standardized } \\
\text { Coefficients } \\
\text { Beta }\end{array}$} & \multirow[t]{2}{*}{ t-value } & \multirow[t]{2}{*}{ Sig. } \\
\hline & B & Std. Error & & & \\
\hline (Constant) & 327846.588 & 608948.418 & & .538 & .592 \\
\hline Age $\left(X_{1}\right)$ & -4352.993 & 12440.359 & -.052 & -.350 & .728 \\
\hline Education $\left(\mathbf{X}_{2}\right)$ & 408519.795 & 294268.331 & 3.243 & $2.991 * *$ & .396 \\
\hline $\begin{array}{l}\text { Material } \\
\text { Possession }\left(\mathbf{X}_{3}\right)\end{array}$ & 205647.797 & 366224.778 & .082 & .562 & .577 \\
\hline Caste $\left(X_{4}\right)$ & -199200.709 & 335226.321 & -1.197 & -.594 & .555 \\
\hline Family type $\left(X_{5}\right)$ & -116137.038 & 232123.976 & -.712 & -.500 & 619 \\
\hline Family size $\left(\mathbf{X}_{6}\right)$ & 328519.795 & 194268.331 & 2.003 & 1.691 & .096 \\
\hline Occupation $\left(\mathbf{X}_{7}\right)$ & -213487.880 & 297868.461 & -1.313 & -.717 & 476 \\
\hline House type $\left(\mathbf{X}_{8}\right)$ & -72599.908 & 113924.334 & -.437 & -.637 & .526 \\
\hline $\begin{array}{l}\text { Social } \\
\text { participation }\left(X_{9}\right)\end{array}$ & -137574.551 & 266771.207 & -.850 & -.516 & .608 \\
\hline $\begin{array}{l}\text { Land holding } \\
\left(\mathbf{X}_{10}\right)\end{array}$ & 348519.795 & 217268.331 & 3.003 & $2.691 * *$ & .196 \\
\hline $\operatorname{Mass}$ media $\left(\mathrm{X}_{11}\right)$ & 40640.640 & 88435.078 & .250 & .460 & .648 \\
\hline $\begin{array}{l}\text { Personal } \\
\text { cosmopolite }\left(\mathbf{X}_{12}\right)\end{array}$ & 361132.755 & 512295.375 & 2.211 & .705 & .484 \\
\hline
\end{tabular}

$\mathrm{r}>2.2664$ significant at $\mathrm{p}=0.01(* *)$

Multiple R sq- 0.583

Table.4 Factor analysis for clubbing of variable into factor based on factor loading for all the respondents

\begin{tabular}{|c|c|c|c|c|c|}
\hline Factors & Variables & $\begin{array}{l}\text { Factor } \\
\text { Loading }\end{array}$ & $\%$ of Variance & Cumulative \% & $\begin{array}{l}\text { Factors } \\
\text { Renamed }\end{array}$ \\
\hline Factor 1 & $\begin{array}{l}\text { Mass media }\left(\mathrm{X}_{11}\right) \\
\text { Family type }\left(\mathrm{X}_{5}\right) \\
\text { Occupation }\left(\mathrm{X}_{7}\right) \\
\text { Family size }\left(\mathrm{X}_{6}\right)\end{array}$ & $\begin{array}{l}.949 \\
.537 \\
.313 \\
.224\end{array}$ & 22.972 & 22.972 & $\begin{array}{l}\text { Family } \\
\text { resource and } \\
\text { exposure }\end{array}$ \\
\hline Factor 2 & $\begin{array}{l}\text { Personal } \\
\text { cosmopolite }\left(\mathrm{X}_{12}\right) \\
\text { Caste }\left(\mathrm{X}_{4}\right)\end{array}$ & $\begin{array}{l}.687 \\
.681\end{array}$ & 18.362 & 41.334 & $\begin{array}{l}\text { Personal } \\
\text { cosmopolite }\end{array}$ \\
\hline Factor 3 & $\begin{array}{l}\text { Material } \\
\text { Possession }\left(\mathrm{X}_{3}\right) \\
\text { Land holding }\left(\mathrm{X}_{10}\right)\end{array}$ & $\begin{array}{l}.650 \\
.610\end{array}$ & 14.055 & 55.389 & Wealth status \\
\hline Factor 4 & $\begin{array}{l}\text { Social } \\
\text { participation }\left(X_{9}\right) \\
\text { Education }\left(X_{2}\right)\end{array}$ & $\begin{array}{l}.509 \\
.259\end{array}$ & 10.388 & 76.512 & $\begin{array}{l}\text { Social } \\
\text { participation }\end{array}$ \\
\hline
\end{tabular}


The table revealed that the variable "House type" distributed with a mean value of 2.86 and S.D. of 1.02. The coefficient of variance was $35.64 \%$ within the range of $1-4$. It is highly consistent in nature.

The table interpreted that the variable "Social participation" distributed with a mean value of 1.14 and S.D. of 0.54 the coefficient of variance was $47.43 \%$ within the range of 1-5. It is highly consistent in nature.

The table interpreted that the variable "Land holding" distributed with a mean value of 1.26 and S.D. of 0.59 the coefficient of variance was $46.48 \%$ within the range of 1-5. It is highly consistent in nature.

The table revealed that the variable "Mass media" distributed with a mean value of 1.58 and S.D. of 0.24. The coefficient of variance was $15.12 \%$ within the range of $0.96-2.08$. It is middle consistent in nature.

The table revealed that the variable "Personal cosmopolite" distributed with a mean value of 1.33 and S.D. of 0.30 . The coefficient of variance was $22.33 \%$ within the range of 0.90-2.47. It is middle consistent in nature.

Table 2 shows that the variable Family Type $\left(X_{5}\right)$ having the ' $t$ ' value of $2.990^{* *}$ and Mass media $\left(\mathrm{X}_{11}\right)$ the ' $\mathrm{t}$ ' value was $4.280 * *$ have recorded a significant impact at $\mathrm{p}=0.01$ level of significance on Yield $\left(\mathrm{Y}_{1}\right)$. Here the value of $\mathrm{R}^{2}$ is 0.497 and we can then conclude that $49 \%$ of the variability embedded with consequent variable Yield $\left(\mathrm{Y}_{1}\right)$, which has been explained with the combination of the 12 causal variables.

Table 3 reveals that the variables Education $\left(\mathrm{X}_{2}\right)$ having the ' $\mathrm{t}$ ' value of $2.991 * *$ and land holding $\left(\mathrm{X}_{10}\right)$ recorded the ' $\mathrm{t}$ ' value of $2.691^{* *}$ have significant impact at $\mathrm{p}=0.01$ level of significance on Income $\left(\mathrm{Y}_{2}\right)$. Here the value of $\mathrm{R}^{2}$ is 0.585 and we can then conclude that $58 \%$ of the variability embedded with consequent variable Income $\left(\mathrm{Y}_{2}\right)$, which has been explained with the combination of the 12 causal variables.

From table 4 the factor 1 has included following 4 variables i.e. Mass media $\left(\mathrm{X}_{11}\right)$, Family type $\left(\mathrm{X}_{5}\right)$, Occupation $\left(\mathrm{X}_{7}\right)$ and Family size $\left(\mathrm{X}_{6}\right)$ which have contributed $22.972 \%$ of variance. The factor loading of all the variables are positive. Factor 1 has been renamed as Family Resource and Exposure.

The factor 2 has included 2 variables i.e. Personal cosmopolite $\left(\mathrm{X}_{12}\right)$ and Caste $\left(\mathrm{X}_{4}\right)$ that have contributed $18.362 \%$ of variance. The factor loading of all the variables are positive. Factor 2 has been renamed as Personal Cosmopolite.

The factor 3 has included 2 variables i.e. Material Possession $\left(\mathrm{X}_{3}\right)$ and Land holding $\left(\mathrm{X}_{10}\right)$ which have contributed $14.055 \%$ of variance. The factor loading of all variables are positive. Factor 3 has been renamed as Wealth Status.

The factor 4 has included 2 numbers of variable under it i.e. Social participation $\left(\mathrm{X}_{9}\right)$ and Education $\left(\mathrm{X}_{2}\right)$ which have contributed $10.388 \%$ of variance. The factor loading of all variables are positive. Factor 4 has been renamed as Social Participation.

\section{References}

Behera, R. N., Nayak, D. K., Anderson, P. and Maren, I. E. (2016). From jhum to broom: Agricultural land use change and food security implications on the Meghalaya Plateau, India. Ambio: A Journal of the Human Environment, 45(1): 63-77.

Borthakur D N, Agriculture in the 1980's: strategy for development in the 
potential areas- North Eastern Hill Region (1982). Paper Presented at the Silver Jubilee Conference of Agriculture Society of India, Calcutta.

Maibangsa, M. (1998). Growth of hill agriculture in Meghalaya. Bihar Journal of Agricultural Marketing, 6(1): 31-38.

Panwar, A.S and Ngachan, S.V. (2010). Agro pastoral based farming system for production enhancement. Sustainable Hill Agriculture: 169-170.

Pareek, U. and Trivedi, G. (1964) Mannual of the Socio- Economic status Scale (Rural). Manasayan Delhi.

Singh N P, Singh A K and Patel D P (2000). Shifting cultivation and its alternate approaches towards sustainable development in North East India, J North Eastern Council, 20(2), 30.

\section{How to cite this article:}

Das, J.K. and Lawanrisha Lyngdoh. 2019. Relationship between Socio-Economic Variables and Production and Income in Agriculture - A Multifactor Analysis. Int.J.Curr.Microbiol.App.Sci. 8(07): 612-618. doi: https://doi.org/10.20546/ijcmas.2019.807.076 